\title{
Wynagrodzenie pracownika naukowego biorącego udział w realizacji filmu naukowego
}

\section{Istota filmu naukowego}

Prawdy naukowe są najczęściej wyrażane przy użyciu słów, symboli matematycznych i znaków graficznych, co znajduje odzwierciedlenie normatywne $\mathrm{w}$ przepisie art. 1 ust. 2 pkt 1 pr.aut ${ }^{1}$. W doktrynie $\mathrm{z}$ reguły za możliwe i dopuszczalne uznaje się wyrażenie prawd naukowych w inny sposób, także w postaci zapisu audiowizualnego ${ }^{2}$. Należy tu odróżnić dwie sytuacje ${ }^{3}$. Po pierwsze, możliwe jest stworzenie dzieła naukowego, którego elementem składowym jest rejestracja audiowizualna. Zwłaszcza w naukach technicznych czy w fizyce analiza i sformułowanie wyników przeprowadzonego eksperymentu jest możliwe dopiero po zarejestrowaniu jego przebiegu specjalną kamerą i odtworzenie w zwolnionym tempie. W naukach medycznych wskazane może okazać się udokumentowanie nowatorskiej metody przeprowadzania zabiegu przez zapis audiowizualny. Można powiedzieć, że osoba dokonująca rejestracji świadczy na rzecz pracownika naukowego określoną usługę. Po drugie, możliwe jest stworze-

* DR hab. Piotr ŚlęZaK, Prof. UŚ - Wydział Radia I Telewizji im. K. Kieślowskiego, Zakład Zarządzania Mediami, Uniwersytet Śląski; e-mail: piotrslezak69@poczta.onet.pl

${ }^{1}$ Ustawa z dnia 4 lutego 1994 r. o prawie autorskim i prawach pokrewnych, tekst jedn. Dz.U. z 2017 r., poz. 880 .

2 Zob. przykładowo: J. Barta, R. Markiewicz, w: Prawo autorskie i prawa pokrewne. Komentarz, red. J. Barta, R. Markiewicz, Warszawa 2011, s. 156; A. Nowicka, w: System Prawa Prywatnego, t. 13, Prawo autorskie, red. J. Barta, Warszawa 2013, s. 114-115; D. Sokołowska, Pojęcie i postacie utworu naukowego w świetle prawa autorskiego, „Ruch Prawniczy Ekonomiczny i Socjologiczny” 2015, nr 2, s. 84-88 i cyt. tam literatura.

${ }^{3}$ Kwestię istoty naukowego utworu audiowizualnego omawiam szczegółowo w pracy P. Ślęzak, Audiowizualny utwór naukowy jako utwór hybrydowy?, „Acta Iuris Stetinensis” nr 2/2017, s. 41-51. 
nie utworu, który w specyficzny sposób łączy fakty naukowe z wyobrażeniami twórców filmowych, co do możliwych sposobów prezentacji tych faktów. Cecha ta przesądza, jak się wydaje, o tym że omawiana kategoria utworów nie należy do dzieł hybrydowych lecz jest podkategorią dzieł audiowizualnych - filmem naukowym. Wydaje się, że w przypadku omawianej kategorii utworów „nasycenie" konkretnego dzieła elementami stworzonymi przez twórców filmowych jest na tyle duże, że stanowi argument przemawiający za stosowaniem do nich nazwy „dzieła audiowizualne” a nie „utwory naukowe”. Autor ma tu na myśli przede wszystkim tzw. dokumenty fabularyzowane, popularnonaukowe filmy $z$ udziałem rzeczywistych postaci oraz animowane. Twórcy przedstawiają fakty i teorie naukowe wykorzystując jako tworzywo artystyczne światło i dźwięk. Można przyjąć, że omawiane dzieło wykazuje powinowactwo z dziełem naukowym wyrażonym słowem, symbolami matematycznymi i znakami graficznymi. Inaczej mówiąc „kino jest widzialną i słyszalną literaturą" przypadku literaturą naukową. Tak więc utwory takie opierają się na metodologii właściwej dla danej dziedziny wiedzy, stosowana jest w nich argumentacja naukowa, weryfikacja bądź falsyfikacja stawianych tez. Wyobraźnia twórców filmowych jest uruchamiana jedynie w celu uatrakcyjnienia przekazywanych treści naukowych. Jest to istotne dla odbiorców niebędących specjalistami z danej dziedziny, a pragnącymi poszerzyć swoją wiedzę. Zasygnalizowane zjawisko najlepiej zilustruje przykład. Wyobraźmy sobie film naukowy omawiający kwestię adaptacji dinozaurów do warunków środowiska, w którym żyły. Z jednej strony film taki przedstawia fakty naukowe ustalone i głoszone przez paleontologów. Mam tu na myśli fakty, których ustalenie jest możliwe na podstawie wykopalisk - dotyczące wyglądu, sposobu poruszania się dinozaurów, ich sposobu zachowania się (np. sposobu odżywiania się czy zachowania w odniesieniu do młodych). Należy założyć, że od czasu narodzin współczesnej paleontologii, rozumianej jako historia życia na Ziemi, na przełomie XVIII i XIX w. naukowcy zgromadzili miliony danych, które pozwalają na rekonstrukcję życia dinozaurów. Jednakże rekonstrukcja te jest jedynie częściowa co pozostawia miejsce dla różnorodnych teorii wyjaśniających konkretne zjawiska oraz dla wyobraźni twórców filmowych. Warto zauważyć, że badaczom nie udało się, jak dotąd jednoznacznie ustalić czy dinozaury były zwierzętami zmiennocieplnymi czy stałocieplnymi ${ }^{5}$. Wyobraźnia twórców filmowych jest uruchamiania w tych momentach, w których nie ma jednoznacznych faktów naukowych pozwalających

\footnotetext{
${ }^{4}$ Pogląd taki wyraził B.W. Lewicki, cyt. za W. Strykowski, Struktura filmu naukowo - dydaktycznego, Poznań 1973, s. 15.

${ }^{5}$ Por informacje na stronach internetowych http://kopalniawiedzy.pl/dinozaury-stalocieplnosczmiennocieplnosc-energetyka-metabolizm,8989, https://pl.wikipedia.org/wiki/Zwierz\%C4\%99_sta\%C5\%82ocieplne, http://www.geekweek.pl/aktualnosci/23257/dinozaury-byly-stalocieplne - dostęp 15.11.2016 r.
} 
zweryfikować czy sfalsyfikować konkretną teorię. Przykładowo można wskazać na fakt, iż przez dziesięciolecia wykopaliska dostarczały wyłącznie informacji o szkieletach, dopiero stosunkowo niedawno odnaleziono pozostałości tkanek miękkich ${ }^{6}$. Jednakże nawet dostępność fragmentów skóry nie przesądza o jej kolorze oraz o ewentualnym upierzeniu zwierzęcia czy też jego braku. Kwestie te „uzupełniają" twórcy filmu kierując się sugestiami paleontologów.

Kwestią wstępną, którą należy rozstrzygnąć, aby określić zasady wynagradzania twórców filmów naukowych jest reżim prawny takich dzieł.

\section{Reżim prawny filmu naukowego}

Aby ustalić reżim prawny filmu naukowego należy uwzględnić, jak sądzę, trzy okoliczności. Po pierwsze, istotę wskazanej kategorii utworów, którą można sprowadzić do stwierdzenia, iż są to utwory, których twórcy przedstawiają fakty i teorie naukowe korzystając ze światła i z dźwięku jako tworzywa. Po drugie, produkcja materiałów audiowizualnych wymaga znacznego zaangażowania organizacyjnego i finansowego. Po trzecie wreszcie, uczelnie (za wyjątkiem szkół filmowych) nie zatrudniają osób profesjonalnie przygotowanych do realizacji materiałów audiowizualnych. Wskazane okoliczności powodują, że produkcji audiowizualnych utworów naukowych podejmują się podmioty zewnętrzne w stosunku do uczelni zatrudniających pracowników naukowych.

Stworzenia audiowizualnego utworu naukowego producent podejmuje się z własnej inicjatywy albo z inicjatywy podmiotu, który z jakichś względów jest zainteresowany powstaniem filmu. W praktyce możliwa jest także koprodukcja w celu stworzenia określonego filmu. Można przyjąć, że typowej sytuacji producentem audiowizualnego utworu naukowego jest podmiot niezależny (zewnętrzny) działający na zlecenie stacji telewizyjnej albo w koprodukcji ze stacją telewizyjną ${ }^{7}$. W Polsce stacje telewizyjne wykonują w ten sposób nałożone na nie przez ustawodawcę zadanie ułatwiania korzystania z oświaty i dorobku nauki (art. 1 ust. 1 pkt 3 ustawy z dnia 29 grudnia 1992 r. o radiofonii i telewizji ${ }^{8}$ ). Zadanie to zostało doprecyzowane w odniesieniu do programów

${ }^{6}$ Przykładem jest scypionyx nazwany Cyrusem; odkryty w pobliżu Neapolu w 1981 r. - zob. informacje zawarte na stronie internetowej https://pl.wikipedia.org/wiki/Scypionyks - dostęp 15.11.2016 r.

7 Tytułem przykładu można wskazać na fabularyzowaną polską serię filmową z 2016 r. „Tajemnice początków Polski” którego producentami byli Zdzisław Cozac i Media Promocja, a koproducentem Telewizja Polska; oraz francusko - kanadyjski serial dokumentalny z 2014 r. „Apokalipsa: pierwsza wojna światowa, wyprodukowany przez studia CC\&C i Ideacom w koprodukcji z France Télévision i TV 5 Québec Canada.

8 Tekst jedn. Dz.U. z 2017 r., poz. 1414. Dalej jako u.r.t. 
publicznej telewizji w art. 21 ust. 2 pkt 5 u.r.t., zgodnie z którym programy i inne usługi telewizji publicznej powinny służyć rozwojowi nauki i oświaty, ze szczególnym uwzględnieniem polskiego dorobku intelektualnego. Popieranie twórczości naukowej mieści się w zakresie „misji” telewizji publicznej (art. 21 ust. la pkt 7 u.r.t.). Ponadto ustawodawca zobowiązał telewizję publiczną do tworzenia i rozpowszechniania audycji oświatowych dla szkół i innych placówek oświatowo - wychowawczych. Treści tych audycji powinny być zgodne z programami nauczania (art. 25 ust. 2 - u.r.t.).

Film naukowy, który powstanie z inicjatywy producenta audiowizualnego albo innego podmiotu zainteresowanego jego powstaniem będzie efektem połączenia wysiłków pracownika/pracowników naukowych oraz osób wchodzących w skład ekipy filmowej. Należy, jak się wydaje, przyjąć że osoby te zawierają porozumienie dotyczące połączenia wysiłków w celu stworzenia filmu naukowego. Muszą to być rzecz jasna działania o charakterze twórczym ${ }^{9}$. W konsekwencji należy uznać, że mamy w tym przypadku do czynienia $\mathrm{z}$ utworem współautorskim.

Producent audiowizualny będzie niekiedy zmuszony do nabycia prawa do „sfilmowania” utworu naukowego. Chodzi tu o uzyskanie prawa do adaptacji kinematograficznej utworu naukowego. Udzielenie stosownego zezwolenia jest wykonywaniem praw zależnych. Będzie to konieczne zwłaszcza wtedy, kiedy film przedstawi fakty naukowe i teorie przedstawione $\mathrm{w}$ konkretnym dziele/ dziełach naukowych. W praktyce, o tym kto jest podmiotem, $\mathrm{z}$ którym producent audiowizualny zawiera umowę jest treść umowy wydawniczej zawartej uprzednio przez wydawnictwo $\mathrm{z}$ autorem tekstu. Jeżeli umowa wydawnicza przenosi na wydawnictwo prawo do sfilmowania utworu naukowego - właściwym do zawarcia umowy z producentem audiowizualnym jest wydawnictwo. Oczywiście możemy założyć, że prawo sfilmowania w przypadku utworu naukowego ma jedynie marginalne znaczenie gospodarcze i umowa wydawnicza nie powinna obejmować tego pola eksploatacji. Jednakże biorąc pod uwagę tendencję wydawnictw do nadmiernego i gospodarczo nieuzasadnionego rozszerzania zakresu pól eksploatacji, które obejmuje umowa wydawnicza nie da się wykluczyć przeniesienia na wydawnictwo prawa do sfilmowania utworu naukowego.

W związku z faktem, iż omawiana kategoria utworów zawiera w sobie składniki o charakterze twórczości naukowej pojawia się pytanie czy znajduje do niej zastosowanie norma $\mathrm{z}$ art. 14 pr.aut., zgodnie z którą instytucji naukowej przysługuje pierwszeństwo opublikowania utworu naukowego pracownika, który stworzył ten utwór w ramach obowiązków wynikających ze stosunku pracy o ile

${ }^{9}$ Kwestia twórczego charakteru działań podejmowanych w ramach porozumienia jest istotna zwłaszcza w odniesieniu do filmowców. Ekipa filmowa może bowiem świadczyć usługi na rzecz producentów dla potrzeb produkcji filmowej (np. najem hal zdjęciowych, sprzętu filmowego - są to działania, w których brak elementu twórczego. Porozumienie jako przesłankę powstania współtwórczości omawia J. Banasiuk, Współtwórczość i jej skutki w prawie autorskim, Warszawa 2012, s. 120-142. 
w umowie o pracę nie postanowiono inaczej. Jeżeli założymy, że film naukowy zostanie wydany na płytach czyli powstaną egzemplarze udostępnione publiczności powstaje kolizja przepisów regulujących utwór audiowizualny i naukowy. Jednakże kolizja ta jest pozorna. Za przyjęciem takiej tezy przemawiają dwa argumenty. Po pierwsze, o istocie filmu naukowego przesądza użycie obrazu i dźwięku jako tworzywa dla wyrażenia treści naukowych. Fakt ten powoduje, że nie można mówić w omawianej sytuacji o kolizji przepisów. Zastosowanie powinny znaleźć przepisy szczególne dotyczące utworów audiowizualnych. Cecha ta przesądza także o atrakcyjności przekazywanych treści dla potencjalnego odbiorcy. Przykładowo dla przeciętnego odbiorcy przekazem atrakcyjnym nie będzie opis prac wykopaliskowych w określonym obiekcie historycznym ale film zawierający komputerową rekonstrukcję tego obiektu może być atrakcyjny. W doktrynie można też spotkać stanowisko odmienne. Zadaniem A. Szewca, który interpretuje audiowizualny utwór naukowy jako dzieło hybrydowe, ,jeżeli ... określona treść może być wyrażona w różny sposób, np. słownie, graficznie albo techniką fotograficzną lub filmową, to przynajmniej w odniesieniu do utworów naukowych o charakterze dzieła powinna decydować jego treść, a nie sposób jej wyrażenia"10 i w konsekwencji w przypadku zasygnalizowanej kolizji przepisami właściwymi dla filmu naukowego będą przepisy odnoszące się do utworów naukowych a nie przepisy właściwe dla utworów audiowizualnych ${ }^{11}$. Po drugie, filmy naukowe powstają głównie "poza” szkołami wyższymi. Ich związek ze światem nauki polega na tym, że pracownik naukowy angażuje się w działania zmierzające do wytworzenia filmu. Dlatego dla oceny faktu publikacji takich filmów nie znajduje zastosowania norma $\mathrm{z}$ art. 14 pr. aut ani postanowienia obowiązującego $\mathrm{w}$ danej uczelni regulamin zarządzania prawami autorskimi i prawami pokrewnymi oraz prawami własności przemysłowej oraz zasad komercjalizacji wyników badań naukowych ${ }^{12}$. Możliwość zastosowania regulaminu pojawia się w przypadku koprodukcji uczelni i podmiotu zewnętrznego przy produkcji filmu naukowego.

\section{Wynagrodzenie za stworzenie filmu naukowego}

Producent audiowizualny ${ }^{13}$ zawiera z przedstawicielami ekipy filmowej (twórcami a niekiedy także artystami wykonawcami) umowy. W tej kwestii produkcja

${ }^{10}$ A. Szewc, Dzieła naukowe i ich status w prawie autorskim, „Państwo i Prawo” 1997, nr 10, s. 27.

11 j.w.

12 Uczelnie są zobligowane do posiadania takiego regulaminu w świetle art. $86 \mathrm{c}$ ustawy z 27 lipca 2005 r. prawo o szkolnictwie wyższym (t.j. Dz.U. z 2016 r., poz. 1842 z późn. zm.).

${ }_{13}$ Pojęcie to zostało omówione w pracy P. Ślęzak, Umowy w zakresie wspótczesnych sztuk wizualnych, s. $316-319$. 
omawianej kategorii dzieł nie różni się od produkcji innych kategorii utworów audiowizualnych. Różnica pojawia się kiedy uwzględnimy fakt, iż stroną umowy są także przedstawiciele środowiska naukowego. Pełnią oni różne role przy produkcji filmu. Mogą wypowiadać się na ekranie albo pełnić rolę tzw. konsultantów naukowych. Nic nie stoi na przeszkodzie, aby wypowiedź na ekranie była utworem naukowym. W „klasycznym” utworze naukowym prawdy naukowe są sformułowane na piśmie; $z$ kolei w audiowizualnym utworze naukowym zostają wypowiedziane (podobnie jak w wykładzie będącym dziełem). Natomiast ostatnia rola jest podobna do funkcji recenzenta w przypadku „klasycznego" dzieła naukowego i polega na ocenie poziomu merytorycznego audiowizualnego utworu naukowego.

Wypada zastanowić się jakiego typu umowy zawierane są w celu stworzenia filmu naukowego. Nie powinno być wątpliwości co do tego, że z przedstawicielami „zawodów filmowych" oraz z naukowcami występującymi na ekranie producent zawiera umowy o produkcję audiowizualną. Należy przyjąć, że w przypadku kiedy wypowiedź pracownika naukowego „na ekranie” nosi cechy utworu w rozumieniu prawa autorskiego - jego wystąpienie jest artystycznym wykonaniem.

Natomiast charakter umów z naukowcami będącymi konsultantami mogą mieć różnoraki charakter. $\mathrm{W}$ przypadku kiedy mamy do czynienia $\mathrm{z}$ „konsultantem na planie filmowym" możliwe jest, jak się wydaje zastosowanie umowy licencyjne. Sytuacja taka ma miejsce jeżeli w czasie konsultacji wykorzystywane są wyniki badań wcześniej przeprowadzonych przez pracownika naukowego. Do zadań takiego konsultanta należy przede wszystkim doradzanie i weryfikacja działań członków ekipy filmowej w ustalonym zakresie. Zwłaszcza naukowy film historyczny może zyskać na wartości jeżeli jest konsultowany np. w zakresie strojów, elementów uzbrojenia, sposobów walki, przebiegu bitwy itd. I odwrotnie brak konsultacji może skutkować błędami merytorycznymi zmniejszającymi wartość naukową dzieła. Należy przyjąć, że o ile w filmie fabularnym „poprawność" historyczna nie jest konieczna ${ }^{14}$, o tyle w naukowym filmie historycznym jest czynnikiem niezwykle istotnym - ponieważ błędy negują wiarygodność utworu audiowizualnego jako przekazu naukowego. Co oczywiście nie oznacza, że utwór audiowizualny nie może prezentować kontrowersyjnych te $z^{15}$.

Z kolei w sytuacji, kiedy konsultacje naukowe dotyczą jedynie poprawności merytorycznej komentarza słownego czy też poprawności tłumaczenia komen-

${ }^{14}$ Naraża twórców filmu co najwyżej na śmieszność. Przykładem może być scena z filmu „Bitwa pod Wiedniem” z 2012 r. w reżyserii R. Martinellego przedstawiająca armaty strzelające z murów bez odrzut, a przecież jest faktem historycznym jest, że oporopowrotnik umożliwiający odrzut samej lufy a nie całego działa Amerykanie zastosowali dopiero pod koniec XIX w.

${ }_{15}$ Przykładem jest serial „Starożytni kosmici”, którego twórcy stawiają i starają się udowodnić tezę, o wizytach obcych cywilizacji na Ziemi. 
tarza w utworze audiowizualnym możliwe wydaje się zawarcie odrębnej umowy dotyczącej „recenzji” komentarza słownego. Wydaje się, że konsultant w omawianej sytuacji może wykonywać powierzone mu czynności na etapie prac nad scenariuszem jak również $w$ okresie realizacji a nawet w postprodukcji. Wydaje się, że recenzja taka może być utworem, zwłaszcza jeżeli pracownik naukowy nie ogranicza się do mechanicznej „korekty” komentarza słownego, ale wskazuje na merytoryczne uzasadnienie wprowadzanych przez siebie zmian. Sytuacja taka jest możliwa choć w praktyce zdarza się niezmiernie rzadko. Najczęściej producentowi zależy właśnie na mechanicznej korekcie. Wówczas wystarczy zawarcie umowy zlecenia.

Możemy założyć, że rejestracja kamerą przebiegu eksperymentu czy wydarzenia generuje konieczność wypłaty wynagrodzenia mieszczącego się w ramach wynagrodzenia za pracę pracownika naukowego. Jest to część wynagrodzenia z tytułu chronionych prawem autorskim wyników badań naukowych niezbędnych do prowadzenia procesu dydaktycznego, albo jest to tzw. „pozostała część wynagrodzenia" za pracę naukową. Natomiast w przypadku udziału w stworzeniu filmu naukowego wynagrodzenie wypłacane konkretnemu naukowcowi nie jest wynagrodzeniem pracownika naukowego - należy wiązać je z udziałem tej osoby w powstaniu utworu audiowizualnego.

Ustawodawca polski, realizując postulat doktryny, zgodnie z którym przedmiotem eksploatacji umownej powinien być utwór, a nie jego twórca ${ }^{16}$ wprowadził domniemanie odpłatności umów (art. 43 ust. 1 pr. aut). Nie przesądza natomiast jakiego rodzaju wynagrodzenie powinno być wypłacane naukowcowi biorącemu udział w realizacji naukowego utworu audiowizualnego. Producenci audiowizualni najczęściej proponują wynagrodzenie ryczałtowe. W praktyce nie występują umowy, w których strony „pominęły” kwestie wynagrodzenia, dlatego należy stwierdzić, że znacznie reguły interpretacyjnej z art. 43 ust. 2 pr.aut jest niewielkie.

Strony w umowie wskazują „,z góry” kwotę należną pracownikowi naukowemu tytułem wynagrodzenia. Wypłacane wynagrodzenie nie ma związku z wydarzeniami następującymi po zawarciu umowy ${ }^{17}$. Wskazana cecha powoduje, że zastosowanie modelu wynagrodzenia ryczałtowego może przynieść negatywne i pozytywne konsekwencje dla pracownika naukowego. Do konsekwencji negatywnych należy zaliczyć fakt, iż w praktyce za niewielką kwotę ${ }^{18}$ producent

${ }^{16}$ Postulat taki sformułował C. Colombet, La portée des autorisations d'exploatation en matière de contrats relatifs au droit d 'auteur, w: Propriétés intellectuelles. Mélanges en l'honneur de André Françon, Paris 1995, s. 64.

${ }_{17}$ Por. P. Ślęzak, Umowy w zakresie..., op.cit., s. 242.

${ }_{18}$ Można założyć, że ryczałt będzie niewielki, ponieważ podmiot inicjujący produkcję audiowizualnego utworu naukowego kieruje się innymi przesłankami niż chęć osiągnięcia sukcesu komercyjnego. Są nimi np. ukazanie i skomentowanie określonych zjawisk społecznych czy historycznych. 
audiowizualny uzyskuje prawo eksploatacji wyników wysiłku intelektualnego naukowca w ramach utworu audiowizualnego. W razie zawarcia umowy o produkcję audiowizualną naukowiec przenosi na producenta prawo do korzystania $\mathrm{z}$ utworu naukowego $\mathrm{w}$ ramach utworu audiowizualnego; natomiast $\mathrm{w}$ przypadku umów z konsultami naukowymi za wystarczającą należy uznać licencję na korzystanie z wyników pracy naukowej, które przybrały postać utworu. Natomiast do konsekwencji pozytywnych należy zaliczyć fakt, iż pracownik naukowy otrzymuje wynagrodzenie wskutek wykonania zobowiązania przez producenta i nie musi czekać na zajście kolejnych zdarzeń i wypłatę kolejnych części wynagrodzenia. Swoistym podtypem wynagrodzenia ryczałtowego jest sytuacja, kiedy strony wskazują w umowie ryczałt za określoną jednostkę obliczeniową (np. dzień na planie filmowym).

\section{Wynagrodzenie za eksploatację filmu naukowego}

Podmiotem uprawnionym $\mathrm{z}$ tytułu majątkowych praw autorskich do audiowizualnego utworu naukowego jest jego producent co wynika z przepisu art. 70 pr. aut. W świetle normy z art. 17 pr.aut. podmiot ten "przejmuje” część przychodu uzyskanego $\mathrm{z}$ dystrybucji filmu w postaci wynagrodzenia, tzn. część ceny biletu kinowego. Kwestią dyskusyjną jest natomiast czy pracownik naukowy także uczestniczy w „podziale” honorariów wynikających z dystrybucji utworu. Kwestię owego „podziału” regulują przepisy art. 70 ust 21 pr.aut. Zgodnie z wolą ustawodawcy współtwórcy i artyści wykonawcy są uprawnieni do dodatkowego wynagrodzenia ze wskazanych postaci dystrybucji utworu audiowizualnego. Aby udzielić odpowiedzi na postawione pytanie należy ustalić czy pracownik naukowy jest współtwórcą audiowizualnego utworu naukowego.

Kwestią wstępną, którą należy rozstrzygnąć jest określenie istoty utworu audiowizualnego. Zauważmy, że z czysto technicznego punktu widzenia utwór audiowizualny (film) jest fotografią wzbogaconą o element ruchu; natomiast kamera filmowa aparatem fotograficznym wyposażonym w mechanizm skokowego przesuwu taśmy. Słowo „fotografia” pochodzi z j. greckiego i oznacza „rysowanie światłem”. Tak więc omawiana kategoria utworów zawiera treści naukowe „narysowane światłem” ${ }^{19}$. Są one zatem wyrażone w konwencji audiowizualnej (filmowej). Oznacza te, że utwory te oparte są na scenariuszu; zamiast klasycznej fabuły zwierają "prawdy” naukowe. Wydaje się, że pracownik

${ }^{19}$ Koncepcje utworu audiowizualnego, jako dzieła „rysowanego światłem” przedstawiam we wcześniejszych pracach: P. Ślęzak, Audiowizualny utwór naukowy..., op. cit., P. Ślęzak, Nowelizacja przepisów prawa autorskiego dotyczących utworów audiowizualnych. Uwagi de lege ferenda, w: Wokół rekodyfikacji prawa cywilnego, pod red. P. Steca i M. Załuckiego, Kraków 2015, s. 462; P. Ślęzak, w: Ustawa o prawie autorskim i prawach pokrewnych. Komentarz, red. P. Ślęzak, Warszawa 2017, s. 460. 
naukowy przyczynia się do ustalenia tych prawd - jako rezultatu naukowego procesu poznawczego Zostają one następnie wplecione w strukturę utworu audiowizualnego. Tak więc prawdy te mają charakter pierwotny, a wyrażenie ich w języku filmu charakter wtórny. Wyrażenie treści naukowych w konwencji audiowizualnej wymaga niekiedy wielokrotnego ich opracowania. Uważam, że pracownik naukowy - jako twórca utworu naukowego o charakterze pierwotnym w stosunku do końcowego rezultatu, którym jest film - nie jest współtwórcą utworu audiowizualnego (filmu). Jest twórcą utworu macierzystego, który podlega kolejnym opracowaniom $\mathrm{w}$ toku produkcji utworu audiowizualnego. Innymi słowy rola pracownika naukowego sprowadza się do wyrażenia prawd naukowych w postaci utworu najczęściej wyrażonego słowem; natomiast rolą twórców filmowych jest transpozycja praw naukowych w konwencji audiowizualnej.

Konstatacja, iż pracownik naukowy nie jest twórcą naukowego utworu audiowizualnego, wywołuje doniosłe konsekwencje praktyczne. Dodatkowe wynagrodzenie z tytułu eksploatacji naukowego utworu audiowizualnego przypada wyłącznie twórcom filmowym. Czy oznacza to, że pracownik naukowy doznaje uszczerbku w zakresie uprawnień majątkowych. Wniosek taki byłby przedwczesny. Wydaje się, że pracownik naukowy powinien otrzymać godziwe wynagrodzenie za przeniesienie na producenta audiowizualnego praw albo za udzielenie licencji za korzystanie $\mathrm{z}$ utworu naukowego w obrębie utworu audiowizualnego jako całości. Wynagrodzenie to powinno, moim zdaniem, uwzględniać także dochody $\mathrm{z}$ dystrybucji naukowego utworu audiowizualnego.

Rozwiązanie to wydaje się, choć nie na pierwszy rzut oka, korzystne dla przedstawicieli środowiska naukowego. Zauważmy bowiem, że dzieło naukowe a typowej postaci (wydrukowanej książki, artykułu w czasopiśmie naukowym) ma ograniczony zasięg. Jest opracowane przez specjalistę w określonej dziedzinie i trafia do adresata, który także najczęściej jest specjalistą $\mathrm{w}$ tej dziedzinie. Natomiast naukowe utwory audiowizualne zawierają „warstwę" przekazującą treści naukowe, uzupełnioną przez „warstwę" stanowiącą emanację inwencji twórców audiowizualnych. Cecha ta powoduje, iż zawartość tych utworów jest dostępna także, a może należałoby powiedzieć przede wszystkim, dla odbiorcy, który nie jest specjalistą z określonej dziedziny naukowej, a chciałby pogłębić swoją wiedzę. W ten sposób produkcja naukowego tworu audiowizualnego nie tylko jest źródłem dochodu dla pracownika naukowego ale również przyczynia się do popularyzowania w społeczeństwie jego poglądów naukowych.

\section{Podsumowanie}

Film naukowy jest specyficznym rodzajem dzieła ponieważ łączy „warstwę” prawd naukowych wyrażonych słowem $\mathrm{z}$ warstwą audiowizualnych środków 
wyrazu. W produkcję tego rodzaju utworów zaangażowani są pracownicy naukowi oraz przedstawiciele zawodów „filmowych”. Pracownicy naukowi pełnią w toku produkcji różne funkcje: wypowiadają się na ekranie (są więc w pewnym sensie bohaterami filmu dokumentalnego czy też artystami wykonawcami) albo są konsultantami naukowymi. W pierwszym przypadku zawierają $\mathrm{z}$ producentem umowę o produkcję audiowizualną a w drugim odrębną umowę o sporządzenie „recenzji” komentarza słownego. Umowy te generują po stronie producenta obowiązek wypłacenia pracownikowi naukowemu wynagrodzenia. Z kolei na etapie dystrybucji naukowego utworu audiowizualnego - uwagi na fakt, że pracownik naukowy nie jest twórcą naukowego utworu audiowizualnego - nie otrzymuje on dodatkowego wynagrodzenia z tytułu dystrybucji. Nie oznacza to jednak, że pracownik naukowy będzie pozbawiony wynagrodzenia. Wydaje się, że najprostszym rozwiązaniem będzie wprowadzenie do umowy zawieranej przez producenta audiowizualnego z pracownikiem naukowym klauzuli przewidującej wynagrodzenie z tytułu dystrybucji.

\section{Bibliografia:}

Banasiuk J., Współtwórczość i jej skutki w prawie autorskim, Warszawa 2012, s. 120-14.

Barta J., Markiewicz R., w: Prawo autorskie i prawa pokrewne. Komentarz, red. J. Barta, R. Markiewicz, Warszawa 2011, s. 156.

Colombet C., La portée des autorisations d'exploatation en matière de contrats relatifs au droit d'auteur, w: Propriétés intellectuelles. Mélanges en l’honneur de André Françon, Paris 1995, s. 6.4

Nowicka A., w: System Prawa Prywatnego, t. 13, Prawo autorskie, red. J. Barta, Warszawa 2013, s. 114-115.

D. Sokołowska, Pojęcie i postacie utworu naukowego w świetle prawa autorskiego, „Ruch Prawniczy Ekonomiczny i Socjologiczny" 2015, nr 2, s. 84-88.

Strykowski W., Struktura filmu naukowo - dydaktycznego, Poznań 1973, s. 15

Szewc A., Dzieła naukowe i ich status w prawie autorskim, „Państwo i Prawo" 1997, nr 10, s. 27.

P. Ślęzak, Audiowizualny utwór naukowy jako utwór hybrydowy?, "Acta luris Stetinensis" nr 2/2017.

P. Ślęzak, Nowelizacja przepisów prawa autorskiego dotyczących utworów audiowizualnych. Uwagi de lege ferenda, w: Wokół rekodyfikacji prawa cywilnego, red. P. Stec, M. Załucki, Kraków 2015, s. 462.

Ślęzak P., Umowy w zakresie współczesnych sztuk wizualnych, s. 316-319.

P. Ślęzak, w: Ustawa o prawie autorskim i prawach pokrewnych. Komentarz, red. P. Ślęzak, Warszawa 2017, s. 460.

Netografia:

http://www.geekweek.pl/aktualnosci/23257/dinozaury-byly-stalocieplne - dostęp 15.11.2016 r. http://kopalniawiedzy.pl/dinozaury-stalocieplnosc-zmiennocieplnosc-energetykametabolizm,8989 - dostęp 15.11.2016 r.

https://pl.wikipedia.org/wiki/Scypionyks - dostęp 15.11.2016 r.

https://pl.wikipedia.org/wiki/Zwierz\%C4\%99_sta\%C5\%82ocieplne - dostęp 15.11.2016 r. 


\section{Streszczenie}

Audiowizualny utwór naukowy to dzieło, w którym twórcy przedstawiają fakty i teorie naukowe wykorzystując jako tworzywo artystyczne światło i dźwięk. Ze względu na występowanie w utworach tego rodzaju warstwy naukowej w ekipie filmowej obok przedstawicieli typowych zawodów filmowych pojawiają się reprezentanci świata nauki. Pełnią oni różne role przy produkcji filmu. Mogą wypowiadać się na ekranie albo pełnić rolę tzw. konsultantów naukowych. Wypowiedź na ekranie może być utworem naukowym (podobnym do klasycznego wykładu akademickiego). Producent filmu zawiera z naukowcami występującymi na ekranie umowy o produkcję audiowizualną. Rola naukowca może sprowadzać się także konsultacji poprawności merytorycznej komentarza słownego czy też poprawności tłumaczenia komentarza w utworze audiowizualnym możliwe jest zarówno zawarcie umowy o produkcję audiowizualną albo odrębnej umowy dotyczącej „recenzji” komentarza słownego. W umowach takich strony przewidują, że naukowiec otrzymuje wynagrodzenie za udział w realizacji filmu. Autor stawia tezę, że naukowcy nie są twórcami filmowymi w związku z czym nie uzyskują dodatkowego wynagrodzenia z tytułu dystrybucji filmu. Dlatego wynagrodzenie za udział w realizacji filmu powinno być ustalone na takiej wysokości aby uwzględniało przewidywalne dochody z eksploatacji naukowego utworu audiowizualnego.

Słowa kluczowe: utwór naukowy, utwór audiowizualny, audiowizualny utwór naukowy.

\section{Remuneration of researcher participating in scientific film production}

\section{Summary:}

The scientific audiovisual work is a work, when the authors represent the facts and scientific theories , using light and sound as an artistic material. Due to the presence in works of this scientific layer, the representatives of science world appear in film crew besides representatives of typical film professions. They play different roles on film production. They can speak out on the screen or perform the role of so-called scientific consultants. The speech on screen can be a scientific work (similar to classic academic lecture). Film producer concludes agreements on audiovisual production with scientists, who perform on the screen. The role of scientist can come down also to a consultation for substantive correctness of verbal comment or either for comment translation correctness on audiovisual work it is possible both, the conclusion of agreement on audiovisual production or a separate agreement relative to "review" of verbal comment. In these agreements the sides foresee that the scientist receive the remuneration for participation in film production. The Author makes the assessment that the scientists are not film creators, therefore they do not receive additional remuneration for film distribution. For this reason the remuneration for participation in film production should be set up at the level, which would consider expected incomes from scientific audiovisual work exploitation.

Keywords: scientific work, audiovisual work, scientific audiovisual work. 